\title{
The nature of preserved forage changes butter organoleptic properties
}

\author{
Catherine HurTaud*, Luc Delaby, Jean-Louis PEYRAud \\ INRA, Agrocampus Rennes, UMR1080, Production du Lait, 35590 Saint-Gilles, France
}

Received 31 July 2006 - Accepted 24 May 2007

\begin{abstract}
Two trials were conducted to study the effect of offering dairy cows maize silage or hay from mixed sward (white clover and ryegrass) in trial 1, or from permanent sward in trial 2, on milk yield and composition and on butter properties. In trial 1, 24 Holstein cows were arranged in a changeover design during two 6-week periods. They were offered either maize silage with soyabean meal or hay plus maize grain. In trial 2, 31 Holstein cows were used in a continuous design. They were offered either maize silage with soyabean meal or hay plus cereal concentrate. With both hay diets, the amounts of concentrate were low and equal even if the energy content of the hay in trial 2 was lower. Therefore, compared with maize diets, energy levels with hay diets were slightly lower in trial 1 ( -2.5 UFL) and greatly lower in trial 2 ( -7.3 UFL). Offering hay significantly decreased daily dry matter intake $\left(-3.1 \mathrm{~kg} \cdot \mathrm{d}^{-1}\right)$, milk yield $\left(-4.3 \mathrm{~kg} \cdot \mathrm{d}^{-1}\right)$, protein content $\left(-2.3 \mathrm{~g} \cdot \mathrm{kg}^{-1}\right)$, and protein and fat yields (respectively, -179 and $-199 \mathrm{~g} \cdot \mathrm{d}^{-1}$ ). Milk fat content was unaffected by hay in trial 1 , but decreased in trial $2\left(-3.0 \mathrm{~g} \cdot \mathrm{kg}^{-1}\right)$. Compared with maize silage, offering hay to dairy cows resulted in a reduced proportion of saturated fatty acids and an increased proportion of monoand polyunsaturated fatty acids in the milk fat (C18:1, C18:2 and C18:3). There was no significant difference in butter-making parameters between hay and maize silage. Nevertheless, the butter produced had a softer texture when cows were offered hay. The butter produced with hay was judged to be softer by trained panellists, with less odour in both trials. In trial 2, hay decreased churning time and significantly decreased butter dry matter content. Yellow colour intensity was higher with hay in trial 1 and with maize silage in trial 2 . The hay diet produced butters with a more rancid flavour.
\end{abstract}

\section{forage / milk / butter / dairy cow / sensory property / texture / colour / flavour}

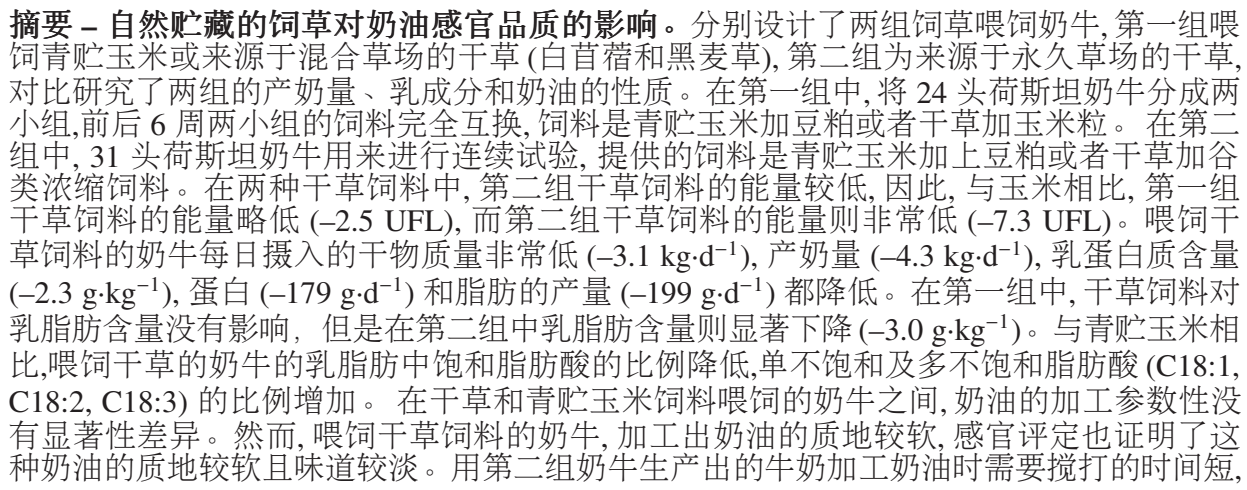

* Corresponding author (通讯作者): Catherine.Hurtaud@ rennes.inra.fr 
并且奶油中干物质的含量显著降低。在第一组中喂饲干草的和第二组中喂饲青贮玉米的奶 油呈黄色, 喂饲干草组的奶油有较重的酸败味。

\title{
草料 / 乳 / 奶油 / 奶牛 / 感官特性 / 质地 / 色泽 / 风味
}

\begin{abstract}
Résumé - La nature du fourrage conservé modifie les propriétés organoleptiques du beurre. Deux essais ont été menés pour étudier l'effet de l'ensilage de maïs ou du foin, issu de prairie mixte (trèfle blanc et ray-grass) dans l'essai 1 ou de prairie permanente dans l'essai 2 , sur la production laitière, la composition du lait et les propriétés du beurre. Dans l'essai 1, 24 vaches laitières Holstein ont été conduites selon un schéma expérimental en inversion avec 2 périodes de 6 semaines. Elles recevaient soit de l'ensilage de maïs avec du tourteau de soja, soit du foin avec du maïs grain. Dans l'essai 2, 31 vaches laitières Holstein ont été conduites selon un schéma expérimental en continu. Elles étaient alimentées soit avec de l'ensilage de maïs et du tourteau de soja, soit avec du foin et un concentré énergétique à base de céréales. Avec les régimes foin, les quantités de concentré étaient faibles et équivalentes même si le foin de l'essai 2 était moins riche en énergie. En conséquence, par rapport au régime ensilage de maïs, les apports énergétiques ont été un peu plus faibles avec le foin dans l'essai 1 ( -2.5 UFL) et beaucoup plus faibles dans l'essai 2 $(-7.3 \mathrm{UFL})$. Le foin a entrâné une diminution significative des quantités ingérées $\left(-3.1 \mathrm{~kg} \cdot \mathrm{j}^{-1}\right)$, de la production laitière $\left(-4.3 \mathrm{~kg} \cdot \mathrm{j}^{-1}\right)$, de la production de matières grasses et de protéines et du taux protéique $\left(-2.3 \mathrm{~g} \cdot \mathrm{kg}^{-1}\right)$. Dans l'essai 1, le taux butyreux n'a pas été modifié, mais a fortement chuté dans l'essai $2\left(-3.0 \mathrm{~g} \cdot \mathrm{kg}^{-1}\right)$. Le profil en acides gras des laits a été modifié par le foin, surtout dans l'essai 2. Le foin a entraîné une diminution des acides gras saturés et une augmentation des acides gras mono- et poly-insaturés, en particulier du C18:1, C18:2 et C18:3. En conséquence, le beurre était moins dur avec le foin. Il n'y a pas eu de différence significative entre le foin et l'ensilage de maïs sur les paramètres de fabrication du beurre. Le beurre produit avec le régime foin a été jugé moins ferme et moins odorant dans les 2 essais, mais avec une flaveur rance plus prononcée. L'intensité de couleur jaune a été plus élevée pour le foin dans l'essai 1 et pour le maiis dans l'essai 2.
\end{abstract}

fourrage / lait / beurre / vache laitière / propriété sensorielle / texture / couleur / flaveur

\section{INTRODUCTION}

The diet offered to dairy cows can have a significant impact on the fatty acid composition of milk fat $[4,5]$. In particular, conserved grass induces an increase in unsaturated fatty acids in milk fat compared with maize silage. This modification of the fatty acid composition, in particular the increase in the $\mathrm{C} 18: 1 / \mathrm{C} 16: 0$ ratio, could affect the organoleptic properties of butter, and as already demonstrated by the Arilait study [2], spreadability of the butter was improved, but the risk of rancidity or oxidation was greater due to an increase in the concentration of unsaturated fatty acids.

There are limited data on impact of forage on the organoleptic characteristics of butter in lowlands. Houssin et al. [15-18] demonstrated that butter properties, colour and texture in particular, were moderately modified by grass or hay silage, in comparison with maize silage.

The interest in hay for cheese-making is partly linked to the absence of butyric spores that may otherwise be present in silage-type forages. Comparisons between cocksfoot-based hays or hay harvested at various elevations in Auvergne or in the Alps showed that some sensory characteristics of Saint-Nectaire-type cheeses differed between forages, although these effects were relatively small [32] and were probably linked to the floristic composition of the hay.

The aim of this study was therefore to characterise the effect of hay on milk yield, milk composition and on the sensory properties of butter and to compare it with that of maize silage. Two trials were conducted with that objective. The first study compared maize silage with good 
quality hay made from ryegrass and white clover swards. The second trial compared maize silage with hay from natural lowland swards, with a wider botanical species variety.

\section{MATERIALS AND METHODS}

\subsection{Experimental diets}

Two types of hay (HA1 and HA2) were compared with two maize silages (MS1 and MS2) during two successive trials in the winters of 2001 and 2002. The objective was to provide minimal levels of energy concentrate to the dairy cows, so as to maximise the specific effects of the forages. In both trials, the quantity of forage offered to dairy cows was equivalent to $95 \%$ of the ad libitum forage intake during two weeks of experimental diet adaptation.

In trial 1, hay from a reseeded sward was composed of a mixture of ryegrass $(27 \%)$ and white clover $(73 \%)$ harvested in July, under good weather conditions and after 56-day regrowth. The sward was reseeded in October 1999 with $30 \mathrm{~kg} \cdot \mathrm{ha}^{-1}$ Ohio ryegrass and $5 \mathrm{~kg} \cdot \mathrm{ha}^{-1}$ of Alice white clover.

In trial 2, hay, from a multispecies complex sward, managed without nitrogen supplementation, was composed of a mixture of hybrid and English ryegrass, incarnate clover, red clover and white clover. Adventices were present. The hay was harvested in late July 2001 after 63 days' regrowth (2nd cycle) following a period of wet weather. The sward had been reseeded in Spring 2000 with $10 \mathrm{~kg} \cdot \mathrm{ha}^{-1}$ "Gladiator" hybrid ryegrass, $10 \mathrm{~kg} \cdot \mathrm{ha}^{-1}$ "Modanta" English ryegrass, $5 \mathrm{~kg} \cdot \mathrm{ha}^{-1}$ "Dipper" red clover, $5 \mathrm{~kg} \cdot \mathrm{ha}^{-1}$ "Dawn" incarnate clover, $1 \mathrm{~kg} \cdot \mathrm{ha}^{-1}$ "Donna" white clover and $1 \mathrm{~kg} \cdot \mathrm{ha}^{-1}$ "Hareng" white clover.

In trial 1, care was taken in diet formulation to ensure that both dietary regimens provided the same amounts of digested starch in the intestine, by taking account of the bypass starch contents in all diet components. Therefore, the hay diet (HA1) was supplemented with $4 \mathrm{~kg}$ maize grain $(95 \%$ maize and 5\% molasses) and $150 \mathrm{~g}$ mineral compound $12-12-5$ (\% of $\mathrm{P}-\%$ of $\mathrm{Ca}-\%$ of $\mathrm{Mg}$ ). The maize diet (MS1) was supplemented with $3 \mathrm{~kg}$ soyabean meal and $300 \mathrm{~g}$ mineral compound 5-25-5 (\% of P - \% of $\mathrm{Ca}-\%$ of $\mathrm{Mg}$ ).

In trial 2, the hay diet (HA2) was supplemented with energy concentrate $(4.4 \mathrm{~kg})(21.5 \%$ wheat, $22 \%$ barley, $17 \%$ wheat bran, $20 \%$ sugarbeet pulp, $15 \%$ rapeseed meal, $2 \%$ molasses, $0.5 \% \mathrm{CaCO}_{3}$, $1 \% \mathrm{NaCl}$ and $1 \% \mathrm{NaHCO}_{3}, \mathrm{DM}$ basis) and $150 \mathrm{~g}$ mineral compound $12-12-5$ (\% of $\mathrm{P}-\%$ of $\mathrm{Ca}-\%$ of $\mathrm{Mg}$ ). The maize diet (MS2) was supplemented with $2.6 \mathrm{~kg}$ soyabean meal and $300 \mathrm{~g}$ mineral compound 5-25-5 (\% of P - \% of $\mathrm{Ca}-\%$ of $\mathrm{Mg}$ ).

The composition and nutritional values of the forages and energy concentrates are shown in Table I.

\subsection{Animals and experimental design}

Trial 1 was conducted according to a changeover experimental design over two 6-week periods with 24 dairy cows divided into 2 groups of 12 based on similarity in lactation number, lactation stage, milk yield, fat and protein yields and contents, liveweight, body condition score and DM intake. Milk yield at the beginning of the trial was on average $28.8 \pm 3.4 \mathrm{~kg} \cdot \mathrm{d}^{-1}$, fat content was $42.4 \pm 5.0 \mathrm{~g} \cdot \mathrm{kg}^{-1}$, protein content was $32.5 \pm 2.0 \mathrm{~g} \cdot \mathrm{kg}^{-1}$, liveweight was $618 \pm 52 \mathrm{~kg}$ and mean lactation stage was $106 \pm 17 \mathrm{~d}$.

In trial 2, cows received two diets over three 5-week periods: period 1: maize silage; period 2: hay; period 3: maize silage. Thirty-one dairy cows were included in this trial. Milk yield at the beginning of the trial was $30.8 \pm 5.7 \mathrm{~kg} \cdot \mathrm{d}^{-1}$ 
Table I. Chemical composition of feeds in both trials.

\begin{tabular}{|c|c|c|c|c|c|c|c|c|}
\hline & \multicolumn{2}{|c|}{ Maize silage } & \multicolumn{2}{|c|}{ Hay $^{1}$} & \multicolumn{2}{|c|}{ Soyabean meal } & \multicolumn{2}{|c|}{ Energy concentrate $^{2}$} \\
\hline & $\begin{array}{c}\text { Trial 1 } \\
\text { MS1 }\end{array}$ & $\begin{array}{c}\text { Trial 2 } \\
\text { MS2 }\end{array}$ & $\begin{array}{c}\text { Trial 1 } \\
\text { HA1 }\end{array}$ & $\begin{array}{c}\text { Trial 2 } \\
\text { HA2 }\end{array}$ & Trial 1 & Trial 2 & Trial 1 & Trial 2 \\
\hline $\mathrm{DM}^{3}(\%)$ & 32.7 & 35.6 & 85.0 & 92.5 & 88.0 & 88.2 & 86.0 & 88.2 \\
\hline $\mathrm{OM}^{4}\left(\mathrm{~g} \cdot \mathrm{kg}^{-1} \mathrm{DM}\right)$ & 966 & 963 & 888 & 919 & 934 & 931 & 980 & 930 \\
\hline Crude protein $\left(\mathrm{g} \cdot \mathrm{kg}^{-1} \mathrm{DM}\right)$ & 70 & 60 & 154 & 111 & 485 & 500 & 99 & 166 \\
\hline Crude fibre $\left(\mathrm{g} \cdot \mathrm{kg}^{-1} \mathrm{DM}\right)$ & 195 & 219 & 282 & 398 & 71 & 74 & 23 & 101 \\
\hline $\mathrm{NDF}^{5}\left(\mathrm{~g} \cdot \mathrm{kg}^{-1} \mathrm{DM}\right)$ & 407 & 450 & 782 & 679 & 151 & 143 & 127 & 281 \\
\hline $\mathrm{ADF}^{6}\left(\mathrm{~g} \cdot \mathrm{kg}^{-1} \mathrm{DM}\right)$ & 235 & 246 & 329 & 444 & 86 & 82 & 31 & 128 \\
\hline $\mathrm{UFL}^{7}\left(\mathrm{~kg}^{-1} \mathrm{DM}\right)$ & 0.90 & 0.88 & 0.77 & 0.62 & 1.19 & 1.19 & 1.24 & 1.05 \\
\hline $\mathrm{LFU}^{8}\left(\mathrm{~kg}^{-1} \mathrm{DM}\right)$ & 1.05 & 1.02 & 1.07 & 1.17 & / & / & / & / \\
\hline $\operatorname{PDIE}^{9}\left(\mathrm{~g} \cdot \mathrm{kg}^{-1} \mathrm{DM}\right)$ & 67 & 66 & 89 & 72 & 236 & 236 & 124 & 107 \\
\hline $\operatorname{PDIN}^{10}\left(\mathrm{~g} \cdot \mathrm{kg}^{-1} \mathrm{DM}\right)$ & 43 & 38 & 96 & 69 & 343 & 343 & 83 & 108 \\
\hline
\end{tabular}

${ }^{1}$ Trial 1: 73\% white clover, $27 \%$ ryegrass, harvested on 17/07/2000 after 56-day regrowth; trial 2: mixture of hybrid and English ryegrass, incarnate clover, red clover and white clover.

${ }^{2}$ Trial 1: $95 \%$ maize, $5 \%$ molasses; trial 2: $22 \%$ barley, $21.5 \%$ wheat, $20 \%$ beet pulp, $17 \%$ wheat bran, $15 \%$ rapeseed meal, $2 \%$ molasses, $0.5 \% \mathrm{CaCO}_{3}, 1 \% \mathrm{NaHCO}_{3}, 1 \% \mathrm{NaCl}$.

${ }^{3} \mathrm{DM}=$ Dry matter.

${ }^{4} \mathrm{OM}=$ Organic matter.

${ }^{5} \mathrm{NDF}=$ Neutral-detergent fibre.

${ }^{6} \mathrm{ADF}=$ Acid-detergent fibre.

${ }^{7} \mathrm{UFL}=$ Feed unit for lactation.

${ }^{8} \mathrm{LFU}=$ Fill unit for lactating dairy cows.

${ }^{9} \mathrm{PDIE}=$ Protein digested in the small intestine supplied by rumen-undegraded dietary protein and by microbial protein from rumen-fermented organic matter [20].

${ }^{10} \mathrm{PDIN}=$ Protein digested in the small intestine supplied by rumen-undegraded dietary protein and by microbial protein from rumen-degraded organic matter [20].

on average, fat content was $40.0 \pm$ $4.5 \mathrm{~g} \cdot \mathrm{kg}^{-1}$, protein content was $29.2 \pm$ $1.9 \mathrm{~g} \cdot \mathrm{kg}^{-1}$, liveweight was $584 \pm 69 \mathrm{~kg}$ and mean lactation stage was $72 \pm 21 \mathrm{~d}$.

\subsection{Measurements}

\subsubsection{Animal performances and milk measurements}

In trial 1 , individual cow feed intakes were recorded individually on a daily basis. During trial 2, the cows were not fed individually, but in batches. The amounts of feed given and refused were then weighed daily and globally for all the cows. The cows were milked twice daily and milk yield was measured at each milking. Fat and protein contents were measured on three days each week (6 milkings) during the first four (trial 1) or three (trial 2) weeks of each period and four days per week (8 milkings) during the last two weeks of each period (both trials). Fat and protein contents were measured with an infrared analyser (Milkoscan, Foss Electric, Hillerød, Denmark).

In trial 1 , the 24 cows' individual milk was sampled once per period at the morning milking. In trial 2, a mixture of individual milk samples from two milkings (evening and morning) from nine cows representative of the 31 cows (same milk yield, average fat and protein contents) was collected once in every period. Total nitrogen content, non-protein 
nitrogen matter (NPN), non-casein nitrogen $(\mathrm{NCN})$, casein and urea were assessed according to the methods described by Hurtaud et al. [19]. Total and soluble calcium were analysed by atomic spectrophotometry absorption on milk yield and milk ultrafiltrate, respectively. Milk fatty acid composition was analysed by gas chromatography after extraction [1].

\subsubsection{Butter manufacture and physicochemical properties}

Butter was manufactured twice during each experimental period. Milk from two consecutive milkings of 12 cows in each treatment group in each period was used in trial 1. The milk from four consecutive milkings of the 31 cows was used in trial 2 . In trial 1, butter from each of the two consecutive milkings was made on the Tuesday (hay treatment) and Wednesday (maize treatment) of the last two weeks of each period ( 2 butter-makings per period) and in trial 2, on each Tuesday of the final two weeks of each period ( 2 butter-makings per period). Milk was stored at $4{ }^{\circ} \mathrm{C}$ until processing. It was subsequently heated to $50{ }^{\circ} \mathrm{C}$ with a hot-plate exchanger, then skimmed with a MM1254 cream separator (Wesfalia, Chateau-Thierry, France). The cream was pasteurised with a hot-plate exchanger $\left(80{ }^{\circ} \mathrm{C}\right.$ for $\left.20 \mathrm{~s}\right)$ and standardised around $400 \mathrm{~g} \cdot \mathrm{kg}^{-1}$ of fat. After pasteurisation, cream was cooled as rapidly as possible at $4{ }^{\circ} \mathrm{C}$. Butter was made as described by Couvreur et al. [7].

Physical measurements were made on the butter 14 days after manufacture. The colour of the butter was measured on three samples (four measurements per sample) with a MINOLTA chromameter [24]. Butter samples were tested for resistance to penetration using a universal testing machine (Instron, model 4501, Norwood, USA) on 3 samples of butter conserved at $4{ }^{\circ} \mathrm{C}$ for $15 \mathrm{~d}$ and on 3 samples conserved at $12{ }^{\circ} \mathrm{C}$ during the preceding $20 \mathrm{~h}$ [7]. Butter $\mathrm{pH}$ and dry matter content (by recording the mass lost by a sample of butter of $5 \pm 1 \mathrm{~g}$ during drying in an oven at $102 \pm 2{ }^{\circ} \mathrm{C}$ for $15 \mathrm{~h}$ ) were also measured.

Butter sensory attributes were evaluated by the sensory analysis laboratory panel of ENILIA of Surgères (Charente-Maritime, France) at a tasting temperature of $14 \pm$ $1{ }^{\circ} \mathrm{C}$, as recommended by standard FIL 99C [12]. This panel comprised 10 trained panellists who were trained according to ISO 8586 standard recommendations [21]. In single sessions, each panel member was requested to evaluate odour (total intensity, rancid, cream, milk, grass, hay and hazelnut), flavour (total intensity, rancid, acidity, bitterness, cream, milk, grass, hazelnut and metal), firmness, and melting in the mouth, giving a score between 0 and 10 (the more intense the criteria was, the greater the score) on a continuous rating scale.

\subsection{Statistical analyses}

Data were analysed according to the GLM procedure of SAS [28]. In trial 1, the statistical model used for analysing milk and butter composition parameters was as follows: $Y_{i j k}=\mu+p_{i}+v_{j}+c_{k}+e_{i j k}$ where $\mu$ was the mean, $p_{i}$ the period effect, $v_{j}$ the cow effect (or batch for butter), $c_{k}$ was the treatment effect and $\mathrm{e}_{\mathrm{ijk}}$ was the residual error.

In trial 2, data were analysed according to the MIXED procedure of SAS [28]. The model tested the effect of period, and orthogonal contrasts were used to analyse the effects of periods 1 (Per1) and 3 (Per3) (maize silage diet) versus period 2 (Per2) (hay diet).

In both trials, sensory assessment scores were analysed according to the CATMOD procedure of SAS [28]. The model only tested the treatment effect. 
Table II. Effect of maize silage (MS) and hay (HA) on DM intake and energy and protein balances.

\begin{tabular}{|c|c|c|c|c|c|c|c|c|c|}
\hline & \multicolumn{4}{|c|}{ Trial 1} & \multicolumn{4}{|c|}{ Trial 2} & \multirow[b]{2}{*}{$P$-value } \\
\hline & MS1 & HA1 & $\mathrm{RSD}^{1}$ & $P$-value & $\begin{array}{l}\text { Per1 } \\
\text { MS2 }\end{array}$ & $\begin{array}{l}\text { Per2 } \\
\text { HA2 }\end{array}$ & $\begin{array}{l}\text { Per3 } \\
\text { MS2 }\end{array}$ & $\mathbf{R S D}^{1}$ & \\
\hline DMI $\left(\mathrm{kg} \cdot \mathrm{d}^{-1}\right)$ & 19.2 & 17.8 & 1.28 & 0.001 & 19.7 & 14.4 & 19.2 & I & I \\
\hline Forage $\left(\mathrm{kg} \mathrm{DM} \cdot \mathrm{d}^{-1}\right)$ & 15.8 & 13.9 & 1.21 & $<0.001$ & 17.0 & 10.3 & 16.0 & l & l \\
\hline Concentrate $\left(\mathrm{kg} \mathrm{DM} \cdot \mathrm{d}^{-1}\right)$ & 3.4 & 3.9 & 0.11 & $<0.001$ & 2.7 & 4.2 & 3.1 & l & / \\
\hline Energy $\left(\mathrm{UFL} \cdot \mathrm{d}^{-1}\right)$ & 17.9 & 15.4 & 1.01 & $<0.001$ & 17.5 & 10.1 & 17.3 & l & / \\
\hline PDIE $\left(g \cdot d^{-1}\right)$ & 1790 & 1696 & 115 & 0.010 & 1755 & 1186 & 1796 & l & / \\
\hline $\operatorname{PDIN}\left(\mathrm{g} \cdot \mathrm{d}^{-1}\right)$ & 1743 & 1634 & 127 & 0.007 & 1563 & 1159 & 1681 & l & l \\
\hline Energy balance $\left(\mathrm{UFL} \cdot \mathrm{d}^{-1}\right)$ & 1.8 & 0.4 & 0.96 & $<0.001$ & 0.8 & -2.6 & 2.7 & l & / \\
\hline PDI balance $\left(\mathrm{g} \cdot \mathrm{d}^{-1}\right)$ & 191 & 289 & 114 & 0.007 & -47 & 17 & 280 & I & I \\
\hline
\end{tabular}

${ }^{1} \mathrm{RSD}=$ Residual standard deviation.

\section{RESULTS}

\subsection{Dairy cow performance and milk composition parameters}

The quality of maize silage used in both trials was similar, as expected (Tab. I). In contrast, the hays were very different. In trial 2, the energy and nitrogen values of the hay were clearly lower (0.62 vs. 0.77 UFL and 72 vs. $89 \mathrm{~g} \cdot \mathrm{kg}^{-1}$ PDIE, and 69 vs. $96 \mathrm{~g} \cdot \mathrm{kg}^{-1}$ PDIN, respectively) than in trial 1 and its fill value (LFU) was higher (1.17 vs. 1.07) (Tab. I).

In both trials, forage intake and total intake were markedly reduced with the hay diet. This reduction was more marked in trial $2\left(-1.4 \mathrm{~kg} \cdot \mathrm{d}^{-1}, P=0.001\right.$ in trial $1 ;-4.9 \mathrm{~kg} \cdot \mathrm{d}^{-1}$, non-statistically tested, in trial 2) (Tab. II). Overall, concentrate intake amounts were low: $21 \%$ of total intake amounts on average. In trial 1, energy and PDI balances were positive for both diets, but energy balance was clearly lower (respectively, 0.4 vs. $1.8 \mathrm{UFL} \cdot \mathrm{d}^{-1}, P<0.001$ ) and PDI balance was higher with the hay diet (respectively, $191 \mathrm{vs.} 289 \mathrm{~g} \cdot \mathrm{d}^{-1}$ of PDI, $P=0.007)$. In trial 2, energy and PDI balances were positive with the maize silage diet, although with the hay diet, the energy balance was highly negative ( -4.4 UFL compared with MS2 average diet) and the
PDI balance was low $\left(-106 \mathrm{~g} \cdot \mathrm{d}^{-1}\right.$ of PDI compared with MS2 average diet). Energy and PDI balances were not or were little different between the two trials with the maize silage diet (for energy balance, 1.8 vs. $1.8 \mathrm{UFL} \cdot \mathrm{d}^{-1}$ and for PDI balance, $191 \mathrm{vs} .123 \mathrm{~g} \cdot \mathrm{d}^{-1}$ of PDI). In contrast, they were numerically much lower in trial 2 than in trial 1 with the hay diet (for energy balance, 0.4 vs. $-2.6 \mathrm{UFL} \cdot \mathrm{d}^{-1}$ and for PDI balance, 289 vs. $17 \mathrm{~g} \cdot \mathrm{d}^{-1}$ of PDI) (Tab. II).

In both trials, cows offered the hay diet had a significantly reduced milk yield $\left(-3.2 \mathrm{~kg} \cdot \mathrm{d}^{-1}, P<0.001\right.$ and $-5.5 \mathrm{~kg} \cdot \mathrm{d}^{-1}$, $P<0.001$ for trials 1 and 2 , respectively), protein content $\left(-1.5 \mathrm{~g} \cdot \mathrm{kg}^{-1}, P<0.001\right.$ and $\left.-3.1 \mathrm{~g} \cdot \mathrm{kg}^{-1}, P<0.001\right)$ and fat and protein production. In trial 1 , fat content was not significantly modified by the hay diet, whereas in trial 2, fat content dropped sharply $\left(-3.0 \mathrm{~g} \cdot \mathrm{kg}^{-1}, P<0.001\right)$. In trial 1 , the cows' liveweight was not affected by treatments, whereas it was significantly decreased by the hay diet in trial $2(-13 \mathrm{~kg}$, $P<0.001$ ) (Tab. III).

Offering hay-based diets to dairy cows resulted in a reduction in milk total nitrogen contents in both trials (Tab. IV). This decrease was essentially linked to that in casein content in trial 1 and to that in casein and soluble protein contents in trial 2. 
Table III. Effect of maize silage (MS) and hay (HA) on milk production and milk composition.

\begin{tabular}{|c|c|c|c|c|c|c|c|c|c|}
\hline & \multicolumn{4}{|c|}{ Trial 1} & \multicolumn{4}{|c|}{ Trial 2} & \multirow[b]{2}{*}{$P$-value } \\
\hline & MS1 & $\overline{\text { HA1 }}$ & $\mathbf{R S D}^{1}$ & $P$-value & $\begin{array}{l}\text { Per1 } \\
\text { MS2 }\end{array}$ & $\begin{array}{l}\text { Per2 } \\
\text { HA2 }\end{array}$ & $\begin{array}{l}\text { Per3 } \\
\text { MS2 }\end{array}$ & $\mathbf{R S D}^{1}$ & \\
\hline $\operatorname{Milk}\left(\mathrm{kg} \cdot \mathrm{d}^{-1}\right)$ & 23.2 & 20.0 & 1.10 & $<0.001$ & 27.2 & 19.1 & 22.1 & 1.39 & $<0.001$ \\
\hline Fat-corrected milk $\left(\mathrm{kg} \cdot \mathrm{d}^{-1}\right)$ & 23.6 & 20.6 & 1.18 & $<0.001$ & 27.3 & 18.1 & 22.0 & 1.41 & $<0.001$ \\
\hline Fat content $\left(\mathrm{g} \cdot \mathrm{kg}^{-1}\right)$ & 41.4 & 42.5 & 2.42 & 0.155 & 40.3 & 36.8 & 40.1 & 1.65 & $<0.001$ \\
\hline Protein content $\left(\mathrm{g} \cdot \mathrm{kg}^{-1}\right)$ & 31.8 & 30.3 & 1.07 & $<0.001$ & 28.9 & 25.7 & 29.3 & 0.74 & $<0.001$ \\
\hline Fat yield $\left(\mathrm{g} \cdot \mathrm{d}^{-1}\right)$ & 957 & 842 & 58.5 & $<0.001$ & 1093 & 697 & 881 & 63.1 & $<0.001$ \\
\hline Protein yield $\left(\mathrm{g} \cdot \mathrm{d}^{-1}\right)$ & 737 & 602 & 31.3 & $<0.001$ & 784 & 488 & 647 & 45.4 & $<0.001$ \\
\hline Liveweight $(\mathrm{kg})$ & 611 & 617 & 12.5 & 0.161 & 579 & 570 & 590 & 9.5 & $<0.001$ \\
\hline
\end{tabular}

${ }^{1} \mathrm{RSD}=$ Residual standard deviation.

Table IV. Effect of maize silage (MS) and hay (HA) on milk composition.

\begin{tabular}{|c|c|c|c|c|c|c|c|c|c|}
\hline & \multicolumn{4}{|c|}{ Trial 1} & \multicolumn{4}{|c|}{ Trial 2} & \multirow[b]{2}{*}{$P$-value } \\
\hline & $\overline{\text { MS1 }}$ & HA1 & $\mathbf{R S D}^{1}$ & $P$-value & $\begin{array}{l}\text { Per1 } \\
\text { MS2 }\end{array}$ & $\begin{array}{l}\text { Per2 } \\
\text { HA2 }\end{array}$ & $\begin{array}{l}\text { Per3 } \\
\text { MS2 }\end{array}$ & $\mathbf{R S D}^{1}$ & \\
\hline$\overline{\text { Crude protein }\left(\mathrm{g} \cdot \mathrm{kg}^{-1}\right)}$ & 33.6 & 32.4 & 1.52 & 0.010 & 30.6 & 28.8 & 31.5 & 0.66 & $<0.001$ \\
\hline Non-protein nitrogen $(\mathrm{NPN})\left(\mathrm{g} \cdot \mathrm{kg}^{-1}\right)$ & 1.55 & 1.36 & 0.12 & $<0.001$ & 1.22 & 1.47 & 1.39 & 0.26 & 0.132 \\
\hline $\operatorname{Urea}\left(\mathrm{mg} \cdot \mathrm{L}^{-1}\right)$ & 239.0 & 184.3 & 45.4 & $<0.001$ & 120.6 & 217.4 & 148.7 & 77.7 & 0.018 \\
\hline True protein $\left(\mathrm{g} \cdot \mathrm{kg}^{-1}\right)$ & 32.1 & 31.0 & 1.48 & 0.022 & 29.4 & 27.3 & 30.1 & 0.68 & $<0.001$ \\
\hline Non-casein nitrogen $(\mathrm{NCN})\left(\mathrm{g} \cdot \mathrm{kg}^{-1}\right)$ & 7.71 & 7.50 & 0.53 & 0.177 & 6.74 & 6.68 & 7.36 & 0.61 & 0.158 \\
\hline Caseins $\left(\mathrm{g} \cdot \mathrm{kg}^{-1}\right)$ & 25.9 & 24.9 & 1.14 & 0.005 & 23.9 & 22.1 & 24.1 & 0.75 & $<0.001$ \\
\hline Soluble proteins $\left(\mathrm{g} \cdot \mathrm{kg}^{-1}\right)$ & 6.16 & 6.14 & 0.47 & 0.868 & 5.51 & 5.21 & 5.97 & 0.40 & 0.005 \\
\hline Ratio casein/protein (\%) & 80.8 & 80.3 & 0.86 & 0.036 & 81.2 & 80.9 & 80.0 & 1.44 & 0.653 \\
\hline Total $\mathrm{Ca}\left(\mathrm{mg} \cdot \mathrm{kg}^{-1}\right)$ & 1235 & 1228 & 124.4 & 0.850 & 1117 & 966 & 1095 & 79.2 & $<0.001$ \\
\hline Soluble $\mathrm{Ca}\left(\mathrm{mg} \cdot \mathrm{kg}^{-1}\right)$ & 282 & 288 & 26.4 & 0.400 & 307 & 241 & 279 & 40.0 & 0.006 \\
\hline Colloidal $\mathrm{Ca}\left(\mathrm{mg} \cdot \mathrm{kg}^{-1}\right)$ & 953 & 940 & 117.9 & 0.702 & 810 & 725 & 816 & 43.3 & $<0.001$ \\
\hline Ratio colloidal $\mathrm{Ca} /$ casein $\left(\mathrm{mg} \cdot \mathrm{g}^{-1}\right)$ & 37.9 & 36.8 & 4.97 & 0.444 & 34.1 & 33.0 & 34.5 & 3.17 & 0.328 \\
\hline
\end{tabular}

${ }^{1} \mathrm{RSD}=$ Residual standard deviation.

Overall, the casein to protein ratio was not modified by diets in trial 2, whereas it was slightly but significantly reduced in trial 1 with the hay diet $(-0.5$ units, $P=0.036)$. In trial 1 , the hay diet induced a significant decrease in non-protein nitrogen and urea (respectively, $-0.19 \mathrm{~g} \cdot \mathrm{kg}^{-1}, P<0.001$ and $-54.7 \mathrm{mg} \cdot \mathrm{L}^{-1}, P<0.001$ ), whereas in trial 2, it only induced an increase in urea $\left(82.8 \mathrm{mg} \cdot \mathrm{L}^{-1}, P=0.018\right)$. The hay diet did not affect the total, soluble or colloidal calcium contents in trial 1, whereas it strongly decreased them in trial 2 . The colloidal calcium to casein ratio did not vary in both trials (Tab. IV).

Hay-based diets induced a significant decrease in the proportion of saturated fatty acids in favour of monounsaturated and polyunsaturated fatty acids (Tab. V). The effect was more clearly seen in trial 2: the unsaturated fatty acid contents increased by 8.8 units percent versus 1.8 in trial 1 . Unsaturated fatty acids were almost $30 \%$ of total fatty acids with the hay diet in 
Table V. Effect of maize silage (MS) and hay (HA) on milk fatty acid composition.

\begin{tabular}{|c|c|c|c|c|c|c|c|c|c|}
\hline \multirow{3}{*}{ Fatty acids, \% } & \multicolumn{4}{|c|}{ Trial 1} & \multicolumn{4}{|c|}{ Trial 2} & \multirow{3}{*}{$P$-value } \\
\hline & \multirow[t]{2}{*}{ MS1 } & \multirow[t]{2}{*}{ HA1 } & \multirow[t]{2}{*}{$\mathbf{R S D}^{1}$} & \multirow[t]{2}{*}{$P$-value } & \multirow{2}{*}{$\begin{array}{l}\text { Per1 } \\
\text { MS2 }\end{array}$} & \multirow{2}{*}{$\begin{array}{l}\text { Per2 } \\
\text { HA2 }\end{array}$} & \multirow{2}{*}{$\begin{array}{l}\text { Per3 } \\
\text { MS2 }\end{array}$} & \multirow[t]{2}{*}{$\mathbf{R S D}^{1}$} & \\
\hline & & & & & & & & & \\
\hline C4:0 & 2.50 & 2.37 & 0.09 & $<0.001$ & 3.55 & 3.01 & 3.19 & 0.23 & 0.002 \\
\hline C5:0 & 0.019 & 0.013 & 0.006 & 0.002 & 0.020 & 0.011 & 0.017 & 0.006 & 0.012 \\
\hline C6:0 & 1.87 & 1.80 & 0.06 & $<0.001$ & 2.61 & 2.20 & 2.48 & 0.13 & $<0.001$ \\
\hline C7:0 & 0.023 & 0.014 & 0.007 & $<0.001$ & 0.005 & 0.004 & 0.020 & 0.011 & 0.082 \\
\hline C8:0 & 1.35 & 1.22 & 0.06 & $<0.001$ & 1.63 & 1.34 & 1.64 & 0.09 & $<0.001$ \\
\hline C9:0 & 0.042 & 0.027 & 0.009 & $<0.001$ & 0.034 & 0.018 & 0.042 & 0.008 & 0.002 \\
\hline C10:0 & 3.37 & 2.92 & 0.26 & $<0.001$ & 3.18 & 2.86 & 3.83 & 0.67 & 0.030 \\
\hline C11:0 & 0.087 & 0.050 & 0.020 & $<0.001$ & 0.058 & 0.037 & 0.079 & 0.012 & $<0.001$ \\
\hline C12:0 & 4.28 & 6.63 & 0.40 & $<0.001$ & 3.97 & 3.27 & 4.69 & 0.39 & $<0.001$ \\
\hline C13:0 & 0.136 & 0.097 & 0.021 & $<0.001$ & 0.103 & 0.086 & 0.119 & 0.01 & $<0.001$ \\
\hline C14:1 & 1.36 & 1.29 & 0.13 & 0.106 & 1.20 & 1.25 & 1.35 & 0.15 & 0.663 \\
\hline C14:0 & 13.3 & 12.5 & 0.45 & $<0.001$ & 12.7 & 11.9 & 13.2 & 0.93 & 0.014 \\
\hline IsoC15 & 0.28 & 0.31 & 0.02 & $<0.001$ & 0.22 & 0.33 & 0.22 & 0.02 & $<0.001$ \\
\hline C15:1 & 0.54 & 0.60 & 0.05 & $<0.001$ & 0.48 & 0.78 & 0.47 & 0.06 & $<0.001$ \\
\hline C15:0 & 1.29 & 1.47 & 0.12 & $<0.001$ & 1.01 & 1.39 & 1.05 & 0.10 & $<0.001$ \\
\hline C16:1 & 2.16 & 2.28 & 0.19 & 0.041 & 1.74 & 2.23 & 1.94 & 0.24 & 0.001 \\
\hline C16:0 & 40.0 & 40.3 & 1.75 & 0.481 & 40.8 & 34.0 & 38.5 & 2.68 & $<0.001$ \\
\hline IsoC17 & 0.32 & 0.38 & 0.03 & $<0.001$ & 0.30 & 0.46 & 0.31 & 0.043 & $<0.001$ \\
\hline C17:1 & 0.75 & 0.90 & 0.05 & $<0.001$ & 0.65 & 1.22 & 0.68 & 0.095 & $<0.001$ \\
\hline C17:0 & 0.53 & 0.73 & 0.03 & $<0.001$ & 0.47 & 0.80 & 0.46 & 0.057 & $<0.001$ \\
\hline C18:0 & 7.77 & 7.52 & 0.74 & 0.255 & 8.67 & 7.66 & 7.60 & 0.75 & 0.142 \\
\hline C18:1 & 16.0 & 17.3 & 1.50 & 0.006 & 14.9 & 22.7 & 16.4 & 2.91 & $<0.001$ \\
\hline C18:2 & 1.98 & 1.75 & 0.18 & $<0.001$ & 1.52 & 2.08 & 1.63 & 0.28 & $<0.001$ \\
\hline $\mathrm{C} 18: 3$ & 0 & 0.46 & 0.07 & $<0.001$ & 0.13 & 0.31 & 0.10 & 0.053 & $<0.001$ \\
\hline Saturated fatty acids & 77.2 & 75.4 & 1.73 & 0.002 & 79.3 & 69.4 & 77.4 & 3.21 & $<0.001$ \\
\hline \multicolumn{10}{|l|}{ Unsaturated fatty acids } \\
\hline Monounsaturated & 20.8 & 22.4 & 1.63 & 0.003 & 19.1 & 28.3 & 21.0 & 2.97 & $<0.001$ \\
\hline Polyunsaturated & 1.98 & 2.21 & 0.17 & $<0.001$ & 1.64 & 2.39 & 1.73 & 0.28 & $<0.001$ \\
\hline Ratio & 2.10 & 2.32 & 0.19 & $<0.0$ & 1.75 & 2.99 & 2.18 & 0.29 & $<0.001$ \\
\hline Ratio C16:1/C16:0 & 0.054 & 0.057 & 0.006 & 0.095 & 0.042 & 0.066 & 0.050 & 0.008 & 0.003 \\
\hline Ratio C14:1/C14:0 & 0.102 & 0.104 & 0.009 & 0.460 & 0.095 & 0.105 & 0.104 & 0.011 & 0.259 \\
\hline Ratio C18:1/C16:0 & 0.40 & 0.44 & 0.06 & 0.050 & 0.37 & 0.68 & 0.44 & 0.120 & $<0.001$ \\
\hline
\end{tabular}

${ }^{1} \mathrm{RSD}=$ Residual standard deviation.

trial 2. The increase in monounsaturated fatty acids with the hay diet was linked to the increase in $\mathrm{C} 15: 1, \mathrm{C} 16: 1, \mathrm{C} 17: 1$ and $\mathrm{C} 18: 1$. The $\mathrm{C} 18: 1 / \mathrm{C} 16: 0$ ratio was marginally increased by the hay diet in trial 1 (0.04 units, $P=0.05)$ and more markedly in trial 2 (0.27 units, $P<0.001)$. The hay diet increased the $\mathrm{C} 18: 1 / \mathrm{C} 18: 0 \mathrm{ra}-$ tio in both trials and the $\mathrm{C} 16: 1 / \mathrm{C} 16: 0$ ratio in trial 2. Polyunsaturated fatty acid content responded differently between trial 1 and trial 2. In trial 1 , the hay diet decreased linoleic acid (C18:2), whereas in trial 2, it significantly increased the same acid $(-0.23, P<0.001$ and +0.50 unit percent, $P<0.001$, respectively). The hay diet induced a significant increase in linolenic acid (C18:3) in both trials, with a greater effect in trial 1. Among the saturated fatty acids, the hay diet reduced the proportion of short-chain fatty acids (C4:0 to C10:0) in both trials. In trial 2 , the reduction 
Table VI. Effect of maize silage (MS) and hay (HA) on butter manufacture.

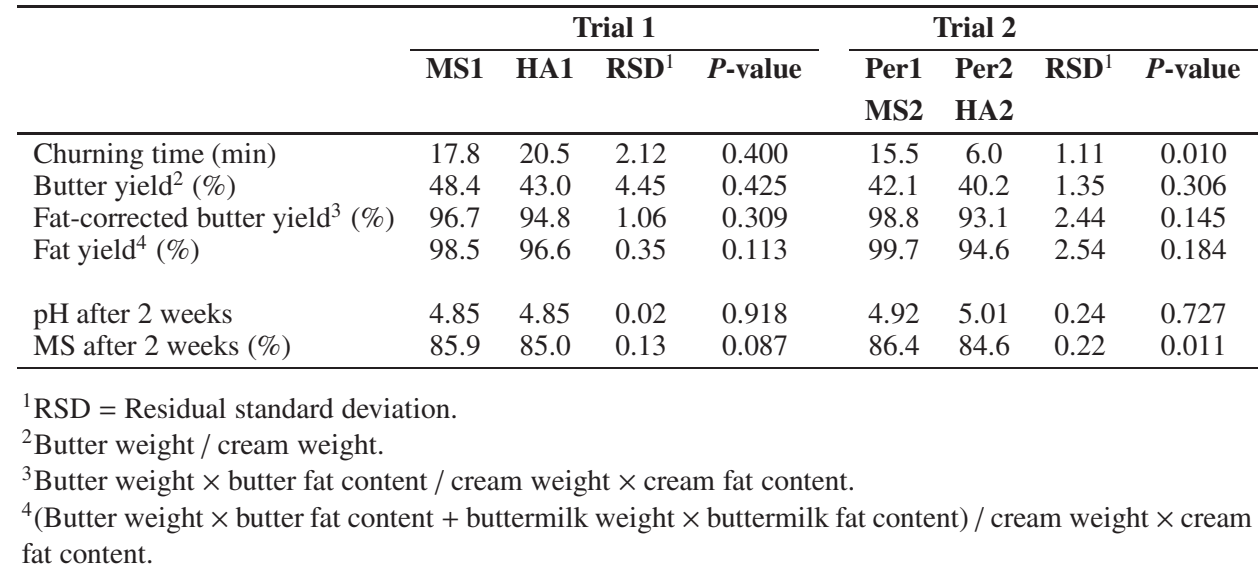

also extended to medium-chain fatty acids, C12:0 and C16:0 in particular. The hay diets induced an increase in the proportion of long-chain odd fatty acids, such as C15:0 and C17:0 (Tab. V).

\subsection{Butter manufacture and organoleptic characteristics of butter}

Offering cows hay-based diets produced no significant effect on milk suitability for butter manufacture (Tab. VI). Butter yield, fat-corrected butter yield and fat yield were not modified in any of the trials. The hay diets did not affect butter $\mathrm{pH}$ and $\mathrm{DM}$ contents. Only churning time was reduced in trial 2 with the hay diet $(-9.5 \mathrm{~min})$ (Tab. VI).

In trial 1, butter texture properties, as measured at $4{ }^{\circ} \mathrm{C}$, were not altered by the hay diet except for forces at 10 and $18 \mathrm{~mm}$ of penetration, which tended to increase at $4{ }^{\circ} \mathrm{C}$ (respectively, $0.022 \mathrm{kN}, P=0.065$ and, $0.04 \mathrm{kN}, P=0.090)$. In trial 2 , butter was much softer with the hay diet, regardless of the measurement temperature. At 5,10 or $18 \mathrm{~mm}$ of penetration into butter, the forces were less than half those noted with butter produced from cows offered the maize diet (Tab. VII).

The sensory analysis panel also found a different effect of the two hay diets on butter firmness in the mouth (Tab. VIII). In trial 1, the hay diet produced butters assessed as slightly less firm in the mouth (respectively, 6.04 vs. $6.79, P=0.036$ ) than with the maize diet, but with no difference in the mouth melting rating. In trial 2, the hay diet produced butters that were also clearly less firm in the mouth but had a much higher mouth melting rating than with the maize diet (Tab. VIII). Maize butters had very similar physical properties across the two trials.

Dietary effects on the colour of butter also differed between trials. In trial 1, butter was more yellow with the hay diet, whereas in trial 2, butter from hay was not as yellow as butter from maize, which was much more coloured than the maize butter in trial 1. This difference in colour, which was measured by reflectance, was also found by the sensory analysis panel in trial 2 (Tabs. VII and VIII). However, in trial 1, the sensory analysis panel did not make any colour distinction between butters from either diet while in trial 2, butter from hay was assessed as significantly 
Table VII. Effect of maize silage (MS) and hay (HA) on butter physical properties.

\begin{tabular}{|c|c|c|c|c|c|c|c|c|}
\hline & \multicolumn{4}{|c|}{ Trial 1} & \multicolumn{4}{|c|}{ Trial 2} \\
\hline & MS1 & HA1 & $\mathbf{R S D}^{1}$ & $P$-value & Per1 & Per2 & $\mathbf{R S D}^{1}$ & $P$-value \\
\hline & & & & & MS2 & HA2 & & \\
\hline \multicolumn{9}{|l|}{ Measurements at $4{ }^{\circ} \mathrm{C}$} \\
\hline Slope $\left(\mathrm{N} \cdot \mathrm{mm}^{-1}\right)$ & 30.42 & 32.17 & 4.10 & 0.581 & 32.61 & 18.37 & 4.94 & 0.102 \\
\hline Force at $5 \mathrm{~mm}(\mathrm{kN})$ & 0.036 & 0.041 & 0.005 & 0.204 & 0.058 & 0.024 & 0.005 & 0.017 \\
\hline Force at $10 \mathrm{~mm}(\mathrm{kN})$ & 0.126 & 0.148 & 0.013 & 0.065 & 0.185 & 0.080 & 0.02 & 0.031 \\
\hline Force at $18 \mathrm{~mm}(\mathrm{kN})$ & 0.33 & 0.37 & 0.026 & 0.090 & 0.41 & 0.21 & 0.050 & 0.053 \\
\hline \multicolumn{9}{|l|}{ Measurements at $13{ }^{\circ} \mathrm{C}$} \\
\hline Slope $\left(\mathrm{N} \cdot \mathrm{mm}^{-1}\right)$ & 17.79 & 16.51 & 3.38 & 0.623 & 15.73 & 6.45 & 1.55 & 0.023 \\
\hline Force at $5 \mathrm{~mm}(\mathrm{kN})$ & 0.019 & 0.020 & 0.006 & 0.655 & 0.023 & 0.009 & 0.002 & 0.025 \\
\hline Force at $10 \mathrm{~mm}(\mathrm{kN})$ & 0.065 & 0.070 & 0.020 & 0.766 & 0.079 & 0.027 & 0.006 & 0.010 \\
\hline Force at $18 \mathrm{~mm}(\mathrm{kN})$ & 0.187 & 0.183 & 0.042 & 0.882 & 0.194 & 0.070 & 0.019 & 0.018 \\
\hline \multicolumn{9}{|l|}{ Colour (chromameter) } \\
\hline L (white index) & 93.6 & 93.3 & 0.50 & 0.457 & 91.3 & 93.1 & 0.12 & 0.003 \\
\hline $\mathrm{a}(\mathrm{red}$ index $)$ & -2.96 & -3.41 & 0.24 & 0.054 & -3.02 & -2.81 & 0.16 & 0.310 \\
\hline b (yellow index) & 12.78 & 15.12 & 0.80 & 0.016 & 18.99 & 11.90 & 0.78 & 0.009 \\
\hline
\end{tabular}

${ }^{1} \mathrm{RSD}=$ Residual standard deviation.

less coloured than butter from maize; it should be noted that the intensity of yellow colour was generally low in both trials regardless of treatment.

Globally, the scores given by the sensory analysis panels for odour and flavour were not very high, the maximum average score hardly exceeding 5 (Tab. VIII). Hay or maize diets did not produce butters very different in taste. In trial 1 , of the fifteen odour and flavour descriptors, only two descriptors were affected by diet: firmness and rancid flavour. In trial 2, eight descriptors were affected by diet: colour, firmness, melting, fat texture, total intensity of odour, odour of cream, odour of hazelnut and rancid flavour. Total intensity of odour tended to be or was stronger with maize butter in both trials (respectively, $0.56, P=0.070$ and $1.75, P=0.003$ ), while butter from the hay diet tended to have a more oxidised metal flavour $(0.42$, $P=0.108$ and $0.34, P=0.102)$. In both trials, the hay diet produced butters with a significantly stronger rancid flavour $(0.33$, $P=0.011$ and $0.58, P=0.013$ ) although the scores of this parameter were below 1 . In trial 2, the magnitude of the differences was greater (Tab. VIII).

\section{DISCUSSION}

\subsection{Effect of hay-based diets on animal performance and milk production}

The marked effects of the hay diets on milk yield were characteristic of nutrient restriction. Indeed, the amounts of DM ingested with hay compared with maize silage were lower, resulting in a lower energy supply. In trial 2, the energy balance was even highly negative. Furthermore, to highlight the forage effect, a low level of concentrate supplementation was used in both trials (maximum $4 \mathrm{~kg} \cdot \mathrm{d}^{-1}$ DM of concentrate). Low milk production with hay diets has already been reported by a number of authors $[14,16,30]$ and is entirely consistent with the milk production and protein content response to 
Table VIII. Effect of maize silage (MS) and hay (HA) on butter characteristics determined by sensory analysis.

\begin{tabular}{|c|c|c|c|c|c|c|}
\hline & \multicolumn{3}{|c|}{ Trial 1} & \multicolumn{3}{|c|}{ Trial 2} \\
\hline & MS1 & HA1 & $P$-value & $\begin{array}{l}\text { Per1 } \\
\text { MS2 }\end{array}$ & $\begin{array}{l}\text { Per2 } \\
\text { HA2 }\end{array}$ & $P$-value \\
\hline \multicolumn{7}{|c|}{ Sensory analysis (1 to 10$)$} \\
\hline Colour & 0.50 & 0.59 & 0.573 & 1.15 & 0.38 & 0.008 \\
\hline \multicolumn{7}{|l|}{ Odour } \\
\hline Total intensity & 4.87 & 4.31 & 0.070 & 5.20 & 3.45 & 0.003 \\
\hline Cream & 3.52 & 2.99 & 0.131 & 3.58 & 2.06 & 0.007 \\
\hline Milk & 1.70 & 1.38 & 0.203 & 1.33 & 0.82 & 0.135 \\
\hline Grass & 0.51 & 0.36 & 0.344 & 0.42 & 0.41 & 0.941 \\
\hline Hay & 0.24 & 0.22 & 0.834 & 0.27 & 0.08 & 0.189 \\
\hline Hazelnut & 0.17 & 0.18 & 0.874 & 0.19 & 0 & 0.043 \\
\hline Rancid & 0.37 & 0.59 & 0.204 & 0.26 & 0.33 & 0.671 \\
\hline \multicolumn{7}{|l|}{ Flavour } \\
\hline Total intensity & 3.71 & 3.48 & 0.398 & 3.52 & 2.70 & 0.096 \\
\hline Acid & 0.53 & 0.37 & 0.256 & 0.23 & 0.31 & 0.600 \\
\hline Bitter & 0.60 & 0.59 & 0.982 & 0.11 & 0.28 & 0.090 \\
\hline Cream & 2.55 & 2.12 & 0.183 & 1.94 & 1.26 & 0.133 \\
\hline Milk & 1.43 & 1.54 & 0.670 & 1.28 & 1.11 & 0.515 \\
\hline Hazelnut & 0.11 & 0.22 & 0.187 & 0.07 & 0.03 & 0.391 \\
\hline Grass & 0.15 & 0.17 & 0.797 & 0.12 & 0.07 & 0.459 \\
\hline Rancid & 0.25 & 0.58 & 0.011 & 0.22 & 0.80 & 0.013 \\
\hline Metal & 0.51 & 0.93 & 0.108 & 0.18 & 0.52 & 0.102 \\
\hline \multicolumn{7}{|c|}{ Texture in mouth } \\
\hline Firmness & 6.79 & 6.04 & 0.036 & 6.68 & 2.73 & $<0.001$ \\
\hline Melting & 3.64 & 3.46 & 0.631 & 2.31 & 4.50 & $<0.001$ \\
\hline Fat & 3.81 & 3.90 & 0.822 & 4.28 & 2.72 & 0.002 \\
\hline
\end{tabular}

energy supplied by the diets [6]. Based on the findings of these authors, the difference in energy supply observed in the present trial (-7.3 UFL) was likely to induce a decrease in milk yield of 5.6 to $7.8 \mathrm{~kg} \cdot \mathrm{d}^{-1}$. The decrease in intake with the hay diet can be explained by the fact that this type of forage has a greater fill value than maize silage. This was more evident in trial 2, where the fill value of hay was 1.17 (vs. 1.07 in trial 1), due to higher crude fibre content [10]. The very sharp decrease in hay intake in trial 2 may also be explained by a palatability problem with that hay. Indeed, the decrease in DM intake $\left(6.2 \mathrm{~kg} \cdot \mathrm{d}^{-1} \mathrm{DM}\right.$ between MS2 and HA2) was sharper than the difference predicted from hay fill value $\left(2 \mathrm{~kg} \cdot \mathrm{d}^{-1} \mathrm{DM}\right)$.
As Couvreur et al. [8] showed that there was no significant interaction between the type of forage and the energy level of the diet, and that the effects of forage and energy restriction were cumulative, the effect of the hay diet in trial 2 could thus have been increased by this cumulative phenomenon, combining the type of forage with energy deficit. The sharp increase in certain milk fatty acids with the hay diet in trial 2, C18:2 and C18:1, may have in part resulted from the energy deficit as the fatty acids can originate from hay and from adipose tissue mobilisation. According to Chilliard et al. [4], adipose tissue triglycerides would contain a significant amount of linoleic acid that might have been used during lipid mobilisation. 


\subsection{Effects of hay diets on milk butter-making capacity and butter sensory characteristics}

\subsubsection{Butter-making capacity}

Except for a decrease in churning time in trial 2, the type of forage had little effect on the suitability of cream for buttermaking. The decrease in churning time with the hay diet in trial 2 could be explained by a decrease in the fat melting point (theoretical melting point calculated from the melting point of each fatty acid: 39.0 vs. $43.0^{\circ} \mathrm{C}$ with the maize diet) due to the increase in unsaturated fatty acids [27]. Indeed, it would appear that cream characterised by high contents of low meltingpoint triglyceride would churn faster than cream poor in these triglycerides [27]. The lack of a hay effect on churning time in trial 1 may be linked to the absence of a treatment effect on triglyceride composition and more specifically on triglyceride melting point (theoretical melting point calculated from the melting point of each fatty acid: 43.8 vs. $43.2{ }^{\circ} \mathrm{C}$ with the maize diet).

\subsubsection{Butter texture properties}

The effect of hay diet on the texture properties of butter was moderate in trial 1 and more pronounced in trial 2 both in terms of physical measurements and sensory panel assessments. Cullinane et al. [9] related texture improvements to fat thermal change characteristics, in particular to the decrease in solid fat content in grass silagebased butter. Indeed, the spreadability index, C18:1/C16:0 ratio and more generally the unsaturated fatty acid contents were increased by the hay diet in trial 2 but remained unchanged in trial 1 . These results were fully consistent with sensory analysis scores, as in trial 2 hay butters were judged to be less firm in the mouth and also more melting. These results were comparable with those of Houssin et al. [17] who also obtained more spreadable butter with hay.

The changes in fatty acid composition with hay, particularly the increase in unsaturated fatty acids, were consistent with the literature data $[5,17]$. These unsaturated fatty acids could come directly from the lipid in hay. Indeed, the presence of linolenic acid in milk could only have a dietary origin [5]. Linolenic acid concentration was often moderate in our trials and much lower than noted by Chilliard et al. [5] (0.38\% on average in our trial vs. more than $1.3 \%$ otherwise with hay diets), perhaps because of the conditions of preservation of the forages. Unsaturated fatty acids in milk could also derive from adipose tissue mobilisation. Hay may also have induced an increase in udder desaturase activity. The increase in both the C16:1/C16:0 and C18:1/C18:0 ratios in trial 2 would indicate a more intense activity of $\Delta 9$-desaturase in the udder [13].

The effects of hay on butter texture properties were more significant in trial 2 . This result was consistent with the effects on fatty acid composition.

The impact of the hay diets in the present study was relatively weak by comparison with that of grass silage [16] or fresh grass [7]. Providing increasing amounts of cut grass to supplement a maize-silage-based diet altered milk fatty acid composition (more unsaturated fatty acids) and clearly improved butter organoleptic properties (a reduced firmness, more colour) [7]. The effect of hay diets cannot be generalised, as shown by the differing responses across the two trials. Conversely, the effects of maize diets on butter characteristics appeared to be rather constant from one year to the other.

\subsubsection{Butter colour}

Hay diets had little effect on butter colour. This finding is consistent 
with that of Houssin et al. [16, 18] on butter and Camembert cheese, and of Nozière et al. [26] on milk. Offering hay diets to dairy cows induced less coloured products than grazing $[31,32]$ or grass silage [15]. According to Nozière et al. [26], $\beta$-carotene contents could account for $40 \%$ of milk colour variability. The rate of decrease in $\beta$-carotene content in preserved grass, and in the milk produced, depends on the light exposure time after cutting [23, 29].

In trial 2, offering a hay diet to dairy cows produced a less coloured butter than in trial 1. The two hays had been harvested under different weather conditions. In trial 1 , hay was harvested under fair weather, whereas in trial 2 , hay had been produced during rainy weather. The colour differences between the two butters from hay could be explained by a greater loss of pigments in trial 2, resulting from prolonged weather exposure and greater loss of carotenoid pigments [23,29].

Cows offered the maize diet produced a milk that gave a more coloured butter in trial 2 than in trial 1 and more coloured than butter made with milk from cows offered the hay diet. This result cannot be a diet-related artefact as cows were given the same amount of soyabean meal in both trials. Also, it was not an artefact linked to the chromameter because the difference was also detected by the sensory analysis panel. This type of result has not been previously documented in the literature. According to Martin et al. [23], the quantities of $\beta$-carotene ingested with maize silage were extremely low. Weiss [33] specified that maize silage contains 1 to $4 \mathrm{mg} \cdot \mathrm{kg}^{-1}$ $\mathrm{DM}$ of $\beta$-carotene vs. 5 to $100 \mathrm{mg} \cdot \mathrm{kg}^{-1}$ $\mathrm{DM}$ in hay and grass silage. An explanation could be that the plant in our study was cropped at an earlier stage (more cobs) or that other pigments were present in the maize, which may have contributed to increasing the yellow colour.

\subsubsection{Butter flavour}

Butters derived from hay diets in trial 1 exhibited sensory characteristics which were similar to those from maize diets. In contrast, differences in sensory properties between hay and maize butters in trial 2 were clearly more marked. This may have been due to a wider floristic diversity in the hay, as can be the case with highland cheeses when comparing graminaceae-based and seeded leguminaceae swards and natural grassland hay as forages in cheese production [32].

The lower total intensity of flavour with hay diets in trial 2 could be the consequence of lower butyric and hexanoic acid contents in cream, as they appear to be the most significant fatty acids which contribute to butter flavour, according to Molimard et al. [25]. The lower cream odour and flavour with hay diets could be linked to reduced cetones in butter [3]. The stronger rancid flavour with the hay diet could be due to butter fat hydrolysis associated with higher humidity of butter under that treatment [22]. It could also be due to the nature of the feed, as shown by Ferlay et al. [11]: lower lipolysis with a corn silage diet compared with ryegrass hay or mountain natural grassland hay.

\section{CONCLUSION}

Compared with maize silage, hay diets with a low level of concentrate supplementation significantly reduced the milk production performance of dairy cows. Furthermore, the effects of hay are variable and depend on its botanical composition, on harvesting conditions, on its production area (plain, highlands or mountain) and are not as important as those of pasture. Nevertheless, compared with maize silage, hay had a positive effect on the nutritional qualities of butter by reducing the saturated fatty acid content and 
therefore increasing the proportion of unsaturated fatty acids, linolenic acid in particular.

Acknowledgements: The authors gratefully acknowledge ONILAIT, La Région Bretagne and Le Conseil Général des Côtes d'Armor, Entremont SA for their financial support, and S. Robin, a farmer of CEDAPA, for his hay. Warm thanks are extended to the farm staff of Méjusseaume (Le Rheu) for cattle measurements, to B. Camier, H. Goudédranche, M.H. Famelart and F. Michel (INRA, Agrocampus Rennes, UMR STLO) and to A. Brasseur, N. Huchet, I. Jicquel, T. Le Mouël, and M. Vérité (INRA, Agrocampus Rennes UMR Production du Lait, Saint Gilles) for their technical assistance. Translation: Philip RousseauCunningham.

\section{REFERENCES}

[1] Apper-Bossard E., Peyraud J.L., Faverdin P., Meschy F., Changing dietary cation-anion difference for dairy cows fed with two contrasting levels of concentrate diets, J. Dairy Sci. 89 (2006) 749-760.

[2] Arilait, Les beurres français. Tartinabilité et composition, Paris, France, 1989.

[3] Bugaud C., Buchin S., Hauwuy A., Coulon J.B., Texture et flaveur du fromage selon la nature du pâturage: cas du fromage d'Abondance, INRA Prod. Anim. 15 (2002) 31-36.

[4] Chilliard Y., Ferlay A., Mansbridge R.M., Doreau M., Ruminant milk fat plasticity: nutritional control of saturated, polyunsaturated trans and conjugated fatty acids, Ann. Zootech. 49 (2000) 181-205.

[5] Chilliard Y., Ferlay A., Doreau M., Effect of different types of forages, animal or marine oils in cow's diet on milk fat secretion and composition, especially conjugated linoleic acid (CLA) and polyunsaturated fatty acids, Liv. Prod. Sci. 70 (2001) 31-48.

[6] Coulon J.B., Rémond B., Variations in milk output and milk protein content in response to the level of energy supply to the dairy cow: a review, Liv. Prod. Sci. 29 (1991) 31-47.

[7] Couvreur S., Hurtaud C., Lopez C., Delaby L., Peyraud J.L., The linear relationship between the proportion of fresh grass in the cow diet, milk fatty acid composition and butter properties, J. Dairy Sci. 89 (2006) 1956-1969.

[8] Couvreur S., Hurtaud C., Delaby L., Peyraud J.L., Effect of haylage or maize silage based diets with or without energy restriction on milk fat properties, in: Lüscher A., Jeangros B., Kessler W., Huguenin O., Lobsige M., Millar N., Suter D. (Eds), Proceeding of the 20th General Meeting of the European Grassland Federation, Luzern, Switzerland, 21-24 June 2004, pp. 1142-1143.

[9] Cullinane N., Aherne S., Connolly J.F., Phelan J.A., Seasonal variation in the triglyceride and fatty acid composition of Irish butter, Ir. J. Food Sci. Technol. 8 (1984) 1-12.

[10] Dulphy J.P., Faverdin P., Jarrige R., Feed intake: the Fill Unit systems, in: Jarrige R. (Ed.), Ruminant Nutrition: Recommanded Allowances and feed Tables, Institut National de la Recherche Agronomique, John Libbey, Eurotext, London, UK, 1989, pp. 61-71.

[11] Ferlay A., Martin B., Pradel P., Coulon J.B., Chilliard Y., Influence of grass-based diets on milk fatty acid composition and milk lipolytic system in Tarentaise and Montbéliarde cow breeds, J. Dairy Sci. 89 (2006) 4026-4041.

[12] FIL 99C, Évaluation sensorielle des produits laitiers par notation. Méthode de référence (1997).

[13] Griinari J.M., Corl B.A., Lacy S.H., Chouinard P.Y., Nurmela K.V.V., Bauman D.E., Conjugated linoleic acid is synthesized endogenously in lactating dairy cows by delta 9-desaturase, J. Nutr. 130 (2000) 2285-2291.

[14] Hoden A., Coulon J.B., Dulphy J.P., Influence de l'alimentation sur la composition du lait. 3. Effets des régimes alimentaires sur les taux butyreux et protéique, Bull. Tech. C.R.Z.V. 62 (1985) 69-79.

[15] Houssin B., Forêt A., Chenais F., Cotinot A., Besnier F., Influence du régime hivernal des vaches laitières sur la qualité organoleptiques des beurres et camemberts, in: Proc. of the 7th symposium Rencontres Recherches Ruminants, Paris, France, 6-7 December 2000, pp. 296-299.

[16] Houssin B., Forêt A., Chenais F., Effect of the winter diet (corn vs. grass silage) of dairy cows on the organoleptic quality of butter and camembert cheese, in: Durand J.L., Emile J.C., Huyghe J.C., Lemaire G. (Eds.), 
Proceeding of the 19th General Meeting of the European Grassland Federation, La Rochelle, France, 27-30 May 2002, pp. 572573.

[17] Houssin B., Chenais F., Forêt A., Influence du régime hivernal des vaches laitières sur la qualité organoleptique des beurres et camemberts, in: Proc. of the 10th symposium Rencontres Recherches Ruminants, Paris, France, 3-4 December 2003, pp. 219222.

[18] Houssin B., Chenais F., Hardy A., Utilisation $\mathrm{du}$ foin par les vaches laitières. Influence sur les performances zootechniques, sur la composition de la matière grasse du lait et sur les qualités organoleptiques des camemberts, in: Proc. of the 12th symposium Rencontres Recherches Ruminants, Paris, France, 78 December 2005, p. 414.

[19] Hurtaud C., Lemosquet S., Rulquin H., Effect of graded duodenal infusions of glucose on yield and composition of milk from dairy cows. 2. Diets based on grass silage, J. Dairy Sci. 83 (2000) 2952-2962.

[20] Institut National de la Recherche (INRA), Ruminant Nutrition: Recommanded Allowances and Feed Tables, R. Jarrige (Ed.), J. Libbey, Eurotext, London, UK, 1989.

[21] ISO 8586-1, Analyse sensorielle. Guide général pour la sélection, l'entraînement et le contrôle des sujets. Partie 1 : sujets qualifiés (1993).

[22] Kuzdzal-Savoie S., Mocquot G., Observations sur les qualités organoleptiques du lait, Ann. Technol. 1 (1960) 5-52.

[23] Martin B., Ferlay A., Pradel P., Rock E., Grolier P., Dupont D., Gruffat D., Besle J.M., Ballot N., Chilliard Y., Coulon J.B., Variabilité de la teneur des laits en constituants d'intérêt nutritionnel selon la nature des fourrages consommés par les vaches laitières, in: Proc. of the 10th symposium Rencontres Recherches Ruminants, Paris, France, 3-4 December 2003, pp. 347-350.

[24] Michalski M.C., Camier B., Briard V., Leconte N., Gassi J.Y., Goudédranche H., Michel F., Fauquant J., The size of native milk fat globules affects physico-chemical and functional properties of Emmental cheese, Lait 84 (2004) 343-358.
[25] Molimard P., Le Quéré J.L., Spinnler H.E., Les lipides et la flaveur des produits laitiers, OCL 4 (1997) 301-311.

[26] Nozière P., Martin B., Grolier P., Durand D., Ferlay A., Gruffat D., Pradel P., Prache S., Rock E., Chilliard Y., Petit M., Évolution des teneurs du plasma et du lait en $\beta$ carotène et autres composés d'intérêt nutritionnel lors d'un changement de régime (ensilage d'herbe puis foin), in: Proc. of the 11th symposium Rencontres Recherches Ruminants, Paris, France, 8-9 December 2004, pp. 63-66

[27] Pointurier H., Adda J., Fabrication du beurre en baratte classique, in: Beurrerie Industrielle : science et technique de la fabrication du beurre, La Maison Rustique, Paris, France, 1969, pp. 288-330.

[28] SAS User's Guide: Statistics. Version 6 Edition 4. SAS Inst., Inc., Cary, NC, USA, 1990.

[29] Shingfield K.J., Salo-Väänänen P., Pahkala E., Toivonen V., Jaakkola S., Piironen V., Huhtanen P., Effect of forage conservation method, concentrate level and propylene glycol on the fatty acid composition and vitamin content of cows' milk, J. Dairy Res. 72 (2005) 349-361.

[30] Verdier I., Coulon J.B., Pradel P., Berdagué J.L., Effect of forage type and cow breed on the characteristics of matured Saint-Nectaire cheeses, Lait 75 (1995) 523-533.

[31] Verdier-Metz I., Coulon J.B., Viallon C., Pradel P., Effet de la conservation du fourrage sur les caractéristiques physicochimiques et sensorielles des fromages, in: Proc. of the 7th symposium Rencontres Recherches Ruminants, Paris, France, 6-7 December 2000, p. 318.

[32] Verdier-Metz I., Pradel P., Coulon J.B., Influence of the forage type and conservation on the cheese sensory properties, in: Durand J.L., Emile J.C., Huyghe J.C., Lemaire G. (Eds.), Proceeding of the 19th General Meeting of the European Grassland Federation, La Rochelle, France, 27-30 May 2002, pp. 604-605.

[33] Weiss W.P., Requirements of fat-soluble vitamins for dairy cows: a review, J. Dairy Sci. 81 (1998) 2493-2501. 